\title{
First record of the genus Eumunida Smith, 1883 (Crustacea, Decapoda, Eumunididae) from the southwestern Atlantic, with the description of a new species
}

\author{
Marcos Tavares ${ }^{1,3}$ \& Daniel Lima ${ }^{1,2}$ \\ ${ }^{1}$ Universidade de São Paulo (USP), Museu de Zoologia (MZUSP). São Paulo, SP, Brasil. \\ ${ }^{2}$ Universidade Federal Fluminense (UFF), Instituto de Biologia (EGB), Departamento de Biologia Marinha (GBM). Niterói, RJ, Brasil. \\ ORCID: http://orcid.org/0000-0002-3039-9134. E-mail: danieljmlima@gmail.com \\ ${ }^{3}$ ORCID: http://orcid.org/0000-0002-7186-5787. E-mail: mdst@usp.br (correspondence author)
}

\begin{abstract}
Eumunida picta Smith, 1883, was considered for over a century an amphi-Atlantic species and the only representative of the genus in the Atlantic Ocean, until being split into three species: E. picta sensu stricto (from the northwestern Atlantic), E. bella de Saint Laurent \& Macpherson, 1990 and E. squamifera de Saint Laurent \& Macpherson, 1990 (from the northeastern and southeastern Atlantic, respectively). Eumunida is now expanded to include a new species, E. notialis, from off the Brazilian coast. Hence, this is the first record of Eumunida and Eumunididae from the southwestern Atlantic. The new species differs from all its Atlantic counterparts in having (1) four hepatic spines; (2) two carapace inframarginal spines; (3) the distal end of the antennal acicle nearly reaching to the articulation between fourth and fifth antennal segments; and (4) the anterolateral spine of the second pleonal tergite obsolete.
\end{abstract}

Key-Words. Anomura; Brazil; Crustacea; Deep sea; Squat lobsters.

\section{INTRODUCTION}

For more than a century Eumunida picta Smith, 1883, was regarded as an amphi-Atlantic species and the only representative of the genus in the Atlantic Ocean (A. Milne-Edwards \& Bouvier, 1900; Chace, 1942; Wenner, 1982). However, de Saint Laurent \& Macpherson (1990) realized that E. picta was actually a complex of three species: E. picta sensu stricto, from the western Atlantic (from off the coast of Massachusetts to the Caribbean coast of Colombia, $40^{\circ} \mathrm{N}-9^{\circ} \mathrm{N}, 200-600 \mathrm{~m}$. See also Baba et al., 2008), E. bella de Saint Laurent \& Macpherson, 1990, from the eastern Atlantic (Canary and Cape Verde Islands, and Morocco to Congo, 396-850 m; d'Udekem d'Acoz, 1999; Matos-Pita \& Ramil, 2014), and E. squamifera de Saint Laurent \& Macpherson, 1990, from the eastern Atlantic (south coast of Namibia, 152-390 m).

Eumunida is now expanded to include a new species from off the coast of Brazil, E. notialis, which is herein described and illustrated. The new species is the first record of the genus Eumunida and the family Eumunididae from the southwestern Atlantic Ocean. A key to the Atlantic species of Eumunida is provided.

\section{MATERIAL AND METHODS}

The studied specimens are deposited either in the collections of the ICM (Instituto de Ciencias del Mar, Barcelona), MNHN (Muséum national d'Histoire naturelle, Paris), MZUSP (Museu de Zoologia, Universidade de São Paulo, Brazil), USNM (National Museum of Natural History, Smithsonian Institution, Washington D.C.).

Measurements: $\mathrm{cl}$, carapace length (rostral spine excluded), taken from the sinus between the rostral spine and the mesial supraorbital spine to the posterior median margin of the carapace, in millimeters $(\mathrm{mm})$. Dates are written in the format day.month. year, with months in lower-case Roman numerals.

The descriptive terminology essentially follows that of de Saint Laurent \& Macpherson (1990) and Baba et al. (2011) (Fig. 1). Abbreviations used include: DSR/V, submersible; F/V, Fishing Vessel; R/V, Research Vessel; SAM, South African Museum; stn, station.

All our attempts to amplify and sequence the CO1 and 16S rRNA genes failed, most probably due to degraded DNA. 


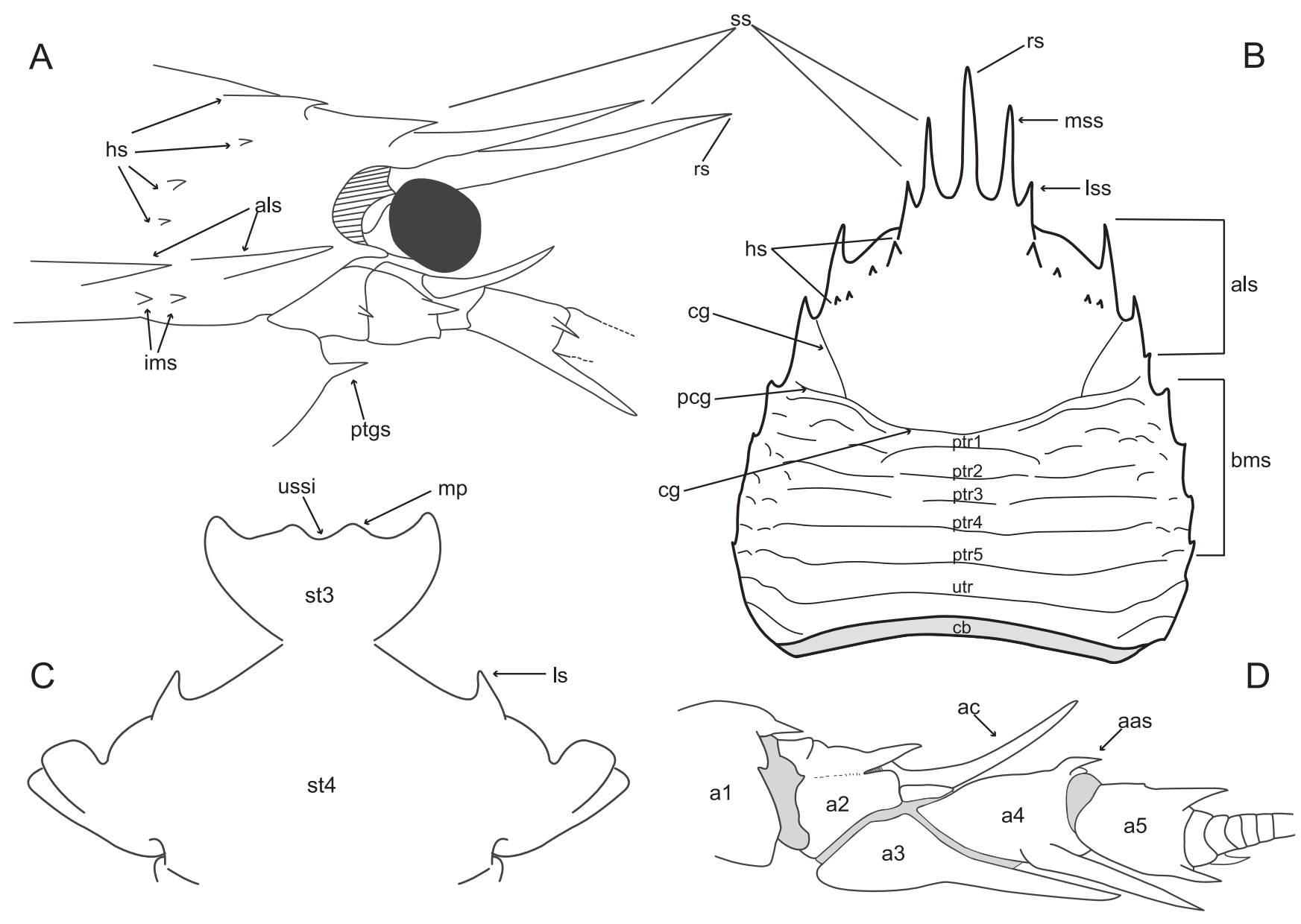

Figure 1. (A) Schematic, lateral view of the anterior region of the cephalothorax. (B) Schematic, dorsal view of the carapace (anterior transverse ridges omitted). (C) Schematic, sternal plastron, ventral view of the third and fourth thoracic sternites (st3, st4, respectively). (D) Schematic, ventral view of the right antennal peduncle. a1-a5, antennal segments 1-5; aas, antennal anteroventrolateral spine; ac, antennal acicle; als, anterolateral spines; bms, branchial marginal spines; cb, carapace posterior margin; cg, cervical groove; hs, hepatic spines; ims, inframarginal spines; Is, lateral spine; Iss, lateral supraorbital spine; mp, median process (setae omitted); mss, mesial supraorbital spine; pcg, postcervical groove; ptgs, pterygostomial spine; ptr, posterior transverse ridge; rs, rostral spine; ss, supraorbital spines; ussi, U-shaped shallow incision; utr, ultimate transverse ridge.

\section{RESULTS AND DISCUSSION}

\section{Eumunididae A. Milne-Edwards \& Bouvier, 1900}

\section{Eumunida Smith, 1883}

Type species: Eumunida picta Smith, 1883, by monotypy. Gender feminine.

\section{Eumunida notialis sp. nov.}

Figs. 2, 3A, C, G, 4A-C, 5A, 6A, 7A, E, F

Type material: Holotype, male, cl 59 mm (MZUSP 25986), F/V "Cordeiro de Deus I", Brazil, off Rio Grande do Sul, $31^{\circ} 45^{\prime} 54.0^{\prime \prime} \mathrm{S}, 49^{\circ} 54^{\prime} 32.4^{\prime \prime} \mathrm{W}$, tangle net, sampling 3, 03.v.2011, $392 \mathrm{~m}$.

Comparative material: Eumunida picta Smith, 1883: 1 juvenile male, cl 10.5 mm, paralectotype (USNM 19293), Massachussetts, off Martha's Vineyeard, R/V "Albatross", stn 1098, 39 $52^{\prime} 48.0^{\prime \prime} \mathrm{N}, 69^{\circ} 43^{\prime} 12.0^{\prime \prime} \mathrm{W}, 11 . v i i i .1882$, trawl, $285 \mathrm{~m}$. 1 juvenile male, cl $10.8 \mathrm{~mm}, 1$ juve- nile female cl $5.4 \mathrm{~mm}$, paralectotypes (USNM 19291), Massachussetts, off Martha's Vineyeard, R/V "Albatross", stn $1038,39^{\circ} 58^{\prime} 00.0^{\prime \prime} \mathrm{N}, 70^{\circ} 06^{\prime} 00.0^{\prime \prime} \mathrm{W}, 21 . \mathrm{ix} .1881$, trawl, $267 \mathrm{~m}$. 1 juvenile male, cl $10.2 \mathrm{~mm}$, paralectotype (USNM 19294), Massachussetts, off Martha's Vineyeard, R/V "Albatross", sth 1152, 39 $58^{\prime} 12.0^{\prime \prime} \mathrm{N}, 70^{\circ} 58^{\prime} 48.0^{\prime \prime} \mathrm{W}$, 04.x.1882, trawl, $210 \mathrm{~m}$. 1 juvenile female, cl $42 \mathrm{~mm}$ (USNM 1136763), off New Jersey, Slope II, CASPS Expedition, DSR/V "Johnson Sea Link", Cruise JSL-1081, stn 5, 01.viii.1981, $200 \mathrm{~m}$. Lectotype, male, cl $16 \mathrm{~mm}$ (USNM 7304), off Delaware Bay, R/V "Albatross", stn 1043, $38^{\circ} 39^{\prime} 00.0^{\prime \prime} \mathrm{N}, 73^{\circ} 10^{\prime} 48.0^{\prime \prime} \mathrm{W}, 10 . x .1881$, trawl, sand, 238 m. 1 male, cl 17 mm (USNM 8891), Virginia, off Chesapeake Bay, R/V "Albatross", stn 2264, 3707'50.2"N, 74³4'19.9"W, 18.x.1884, trawl, gray sand, 305 m. 1 ovigerous female, cl 35 mm (USNM 268766), South Carolina, off Charleston, R/V "Oregon II", Cruise 33, stn 11744, $32^{\circ} 34^{\prime} 12.0^{\prime \prime} \mathrm{N}, 77^{\circ} 37^{\prime} 12.0^{\prime \prime} \mathrm{W}$, 29.i.1972, depth unknown. 1 male, cl 44 mm (USNM 135265), east of Mississippi Delta, Louisiana, Gulf of Mexico, R/V "Oregon II", Cruise 79,

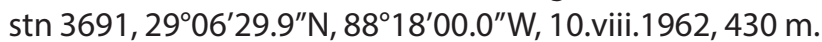

Eumunida bella de Saint Laurent \& Macpherson, 1990: 1 male, cl 25 mm, paratype (USNM 22913), western 
Sahara, Cape Bojador, R/V “Talisman”, stn 73, 2539'00.0” $N$, $18^{\circ} 58^{\prime} 12.0^{\prime \prime} \mathrm{W}, 09 . v i i .1883,698 \mathrm{~m}$.

Distribution: So far known only from the type locality.

Etymology: The species name is derived from the Latin notialis (southern); a reference to its discovery in the southwestern Atlantic.

Diagnosis: Carapace with three anterolateral spines; ultimate transverse ridge entire across carapace; four hepatic spines; two inframarginal spines below anterolateral spines. Anterolateral spine of second pleonal tergite obsolete. Fourth antennal segment with strong, acute spine on anteroventrolateral angle. Antennal acicle spiniform, slender, extending to almost the articulation between fourth and fifth antennal segments. Cheliped propodus without dorsolateral and dorsomesial, longitudinal rows of spines; carpus without longitudinal row of strong spines on dorsomesial surface, armed with three distal spines (dorsal, dorsomesial, ventromesial). Third thoracic sternite with shallow, U-shaped anterior margin.

Description: Carapace slightly wider than long (excluding rostral spine). Gastric region well defined, strongly convex. Four hepatic spines; first spine strong, near base of lateral supraocular spine; second and third hepatic spines much smaller than first, subequal in size; fourth spine smallest, located below the third spine (Figs. 1, 5A, 6A). Cervical groove (Fig. 2) bifurcating downward to form postcervical groove. Grooves separating cardiac and branchial areas well developed. Transverse ridges as illustrated (Figs. 2, 3C), bordered with dense short setae anteriorly. Anterior branchial region smooth, with few minute squamiform granules. Six transverse ridges behind cervical groove, first to fifth entire medially, interrupted laterally; ultimate transverse ridge entire across carapace (Figs. 1, 2). Three anterolateral spines

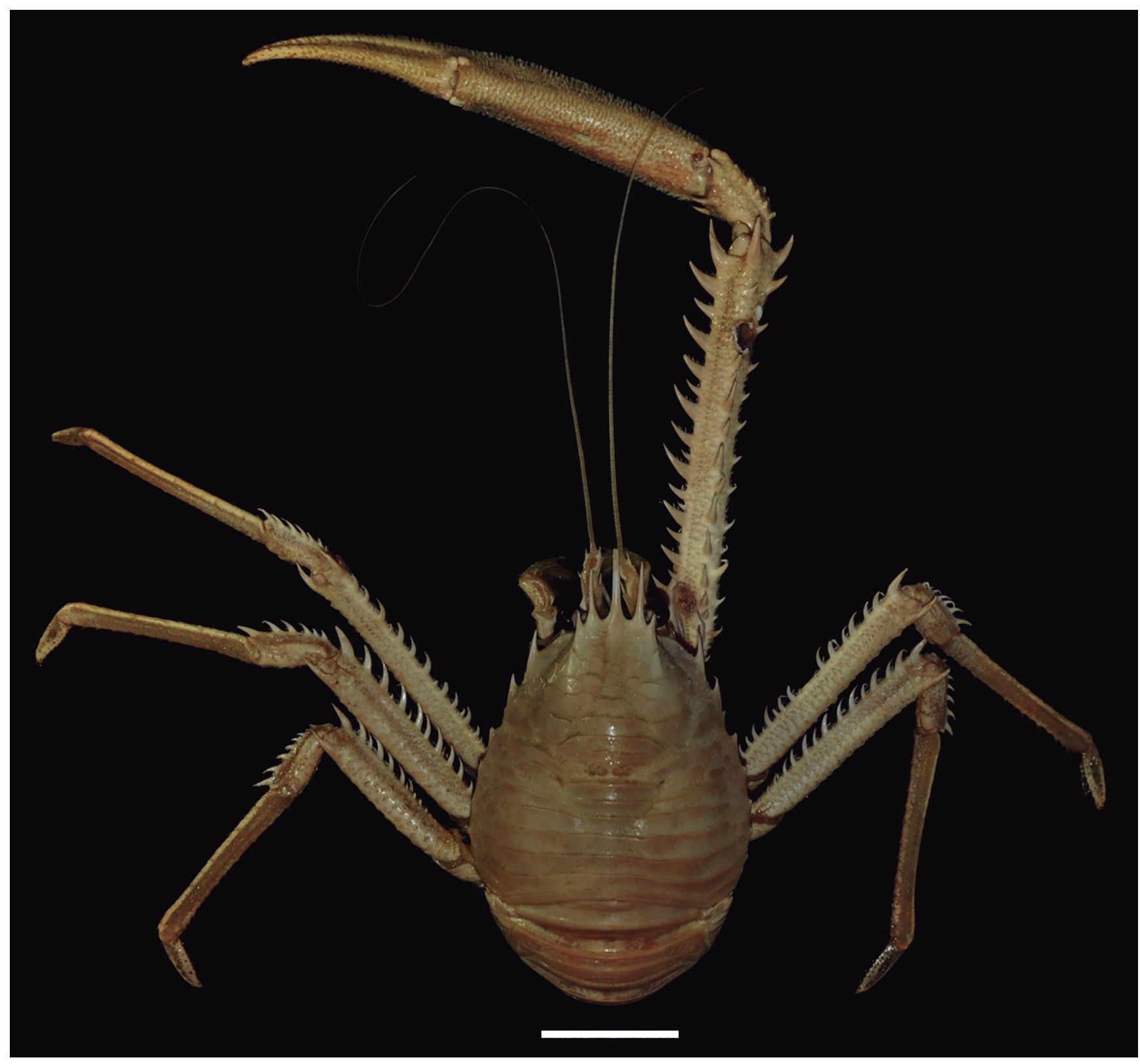

Figure 2. Eumunida notialis sp. nov., holotype, male, cl 59 mm (MZUSP 25986). Habitus, dorsal view. Scale bar: $30 \mathrm{~mm}$. 


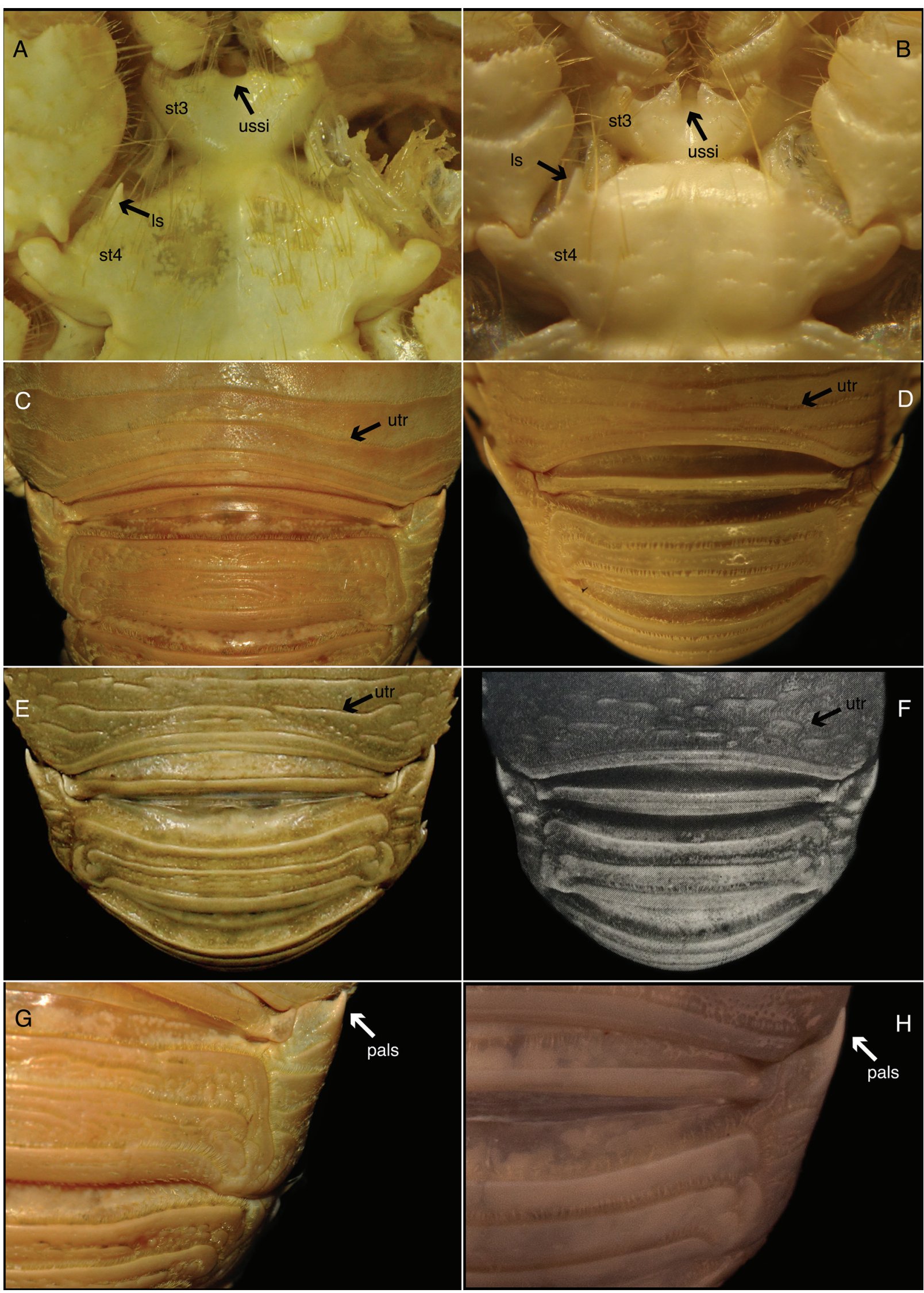

Figure 3. (A, C, G) Eumunida notialis sp. nov., holotype, male, Cl 59 mm (MZUSP 25986). (B, E, H) Eumunida bella de Saint Laurent \& Macpherson, 1990. (B, H) Paratype, male, cl 25 mm (USNM 22913). (E) Holotype, male, cl 46 mm (MNHN-IU-2014-10257). (D) Eumunida picta Smith, 1883, lectotype, male, cl 16 mm (USNM 7304 ). (F) Eumunida squamifera de Saint Laurent \& Macpherson, 1990, holotype, female, cl 32 mm (SAM A 15376), after de Saint Laurent \& Macpherson (1990: 652, fig. 2C). (A, B) Third and fourth thoracic sternites, ventral view (st3, st4, respectively). (C-F) Posterior region of the carapace and first and second pleonal somites, dorsal view. $(G, H)$ Detail of the second pleonal tergite, dorsal view. Is, lateral spine; pals, second pleonal tergite anterolateral spine; ussi, U-shaped shallow incision; utr, ultimate transverse ridge. Photograph (3E) by Laura Flamme (MNHN). 
anterior to postcervical groove, posteriormost spine minute (Figs. 1, 2). Branchial margins distinctly convex, armed with four spines decreasing in size posteriorly. Carapace greatest width at the level of fourth branchi- al marginal spine. Two supraorbital spines; mesial supraorbital spine longest, much more than half length of rostral spine, acute; lateral supraorbital spine much less than half length of mesial supraorbital spine, acute

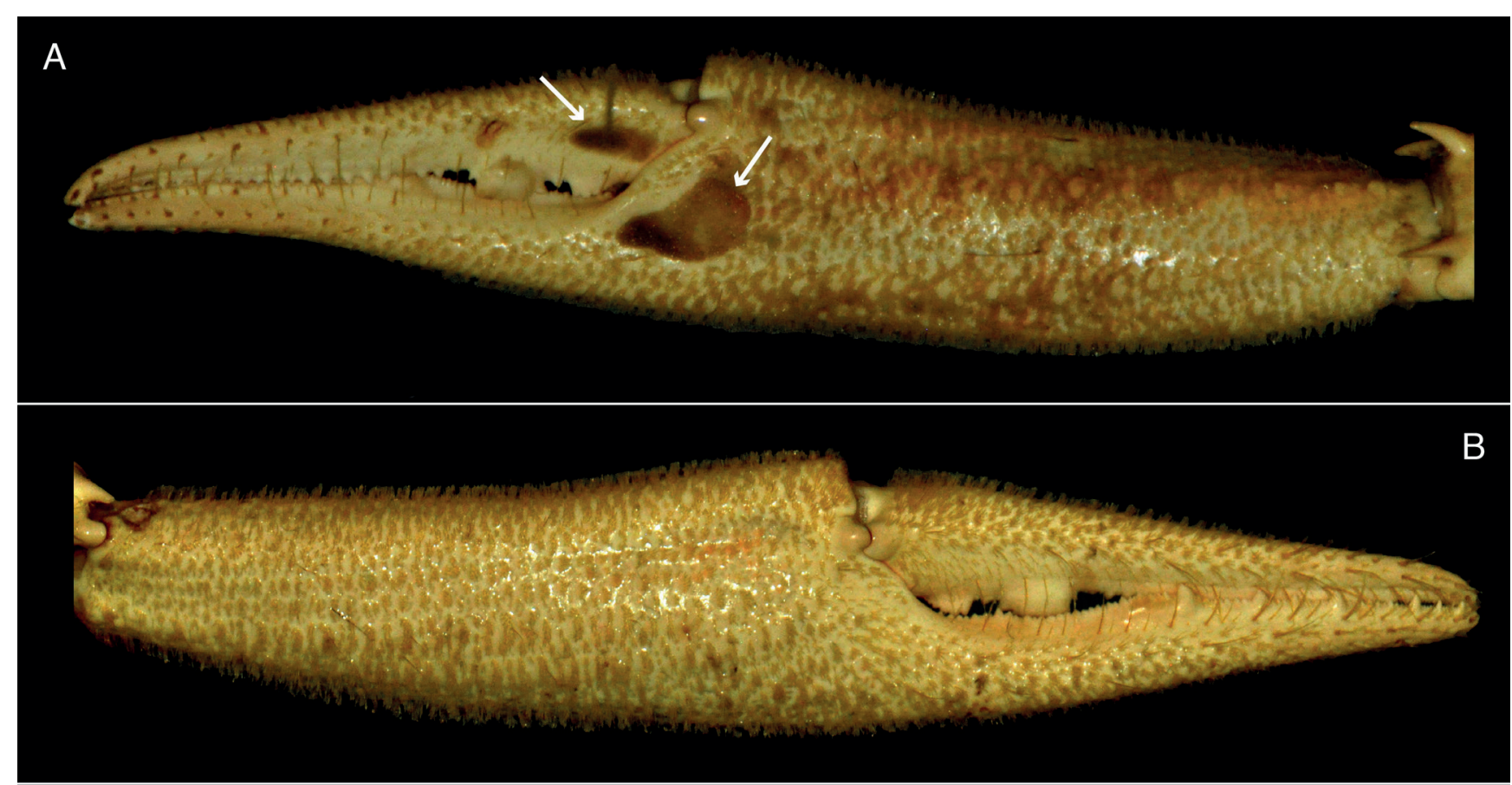

C

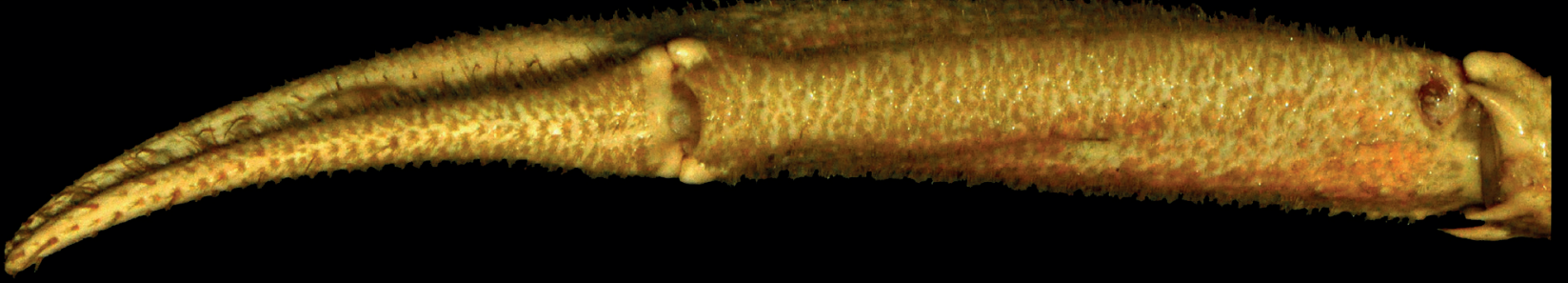

D

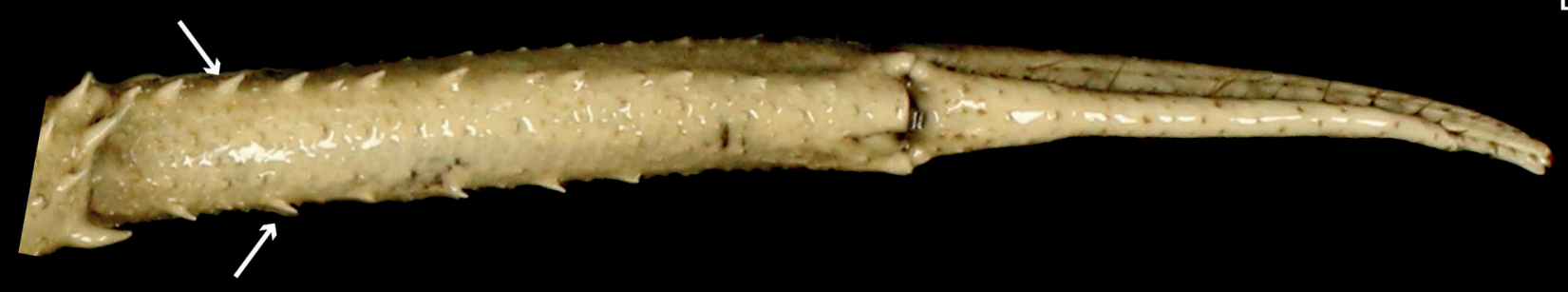

$E$

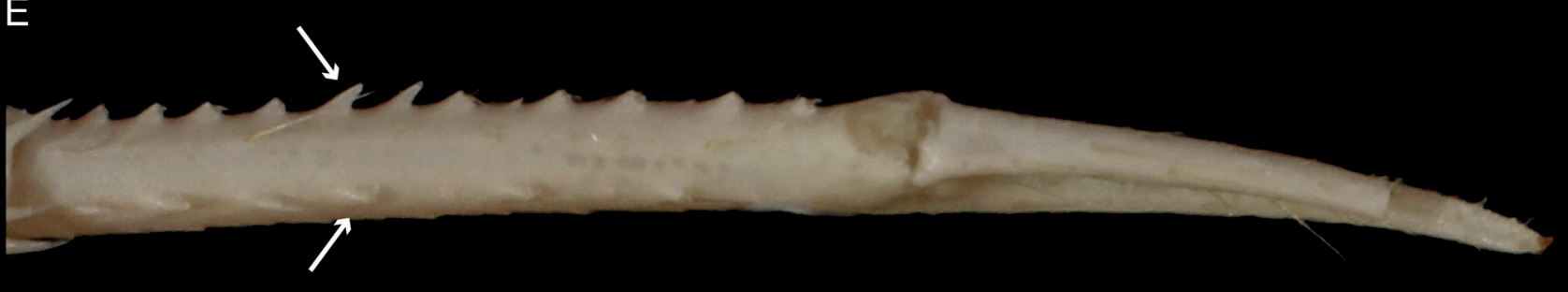

Figure 4. (A-C) Eumunida notialis sp. nov., holotype, male, cl 59 mm (MZUSP 25986). (D) Eumunida bella de Saint Laurent \& Macpherson, 1990, holotype, male, cl 46 mm (MNHN Ga 517). (E) Eumunida squamifera de Saint Laurent \& Macpherson, 1990, paratype, female, cl 11 mm (MNHN-IU-5561). (A-C) Right chela, mesial, lateral and dorsal views, respectively; arrows: pads near bases of fixed finger and dactylus. (D) Left chela, dorsal view; arrows: dorsolateral and dorsomesial, longitudinal rows of spines on the cheliped propodus, respectively. (E) Left chela, dorsal view; arrows: dorsolateral and dorsomesial, longitudinal rows of spines on the cheliped propodus, respectively. Photographs (4D, E) by Laura Flamme (MNHN) and Marie Hennion (MNHN), respectively. 


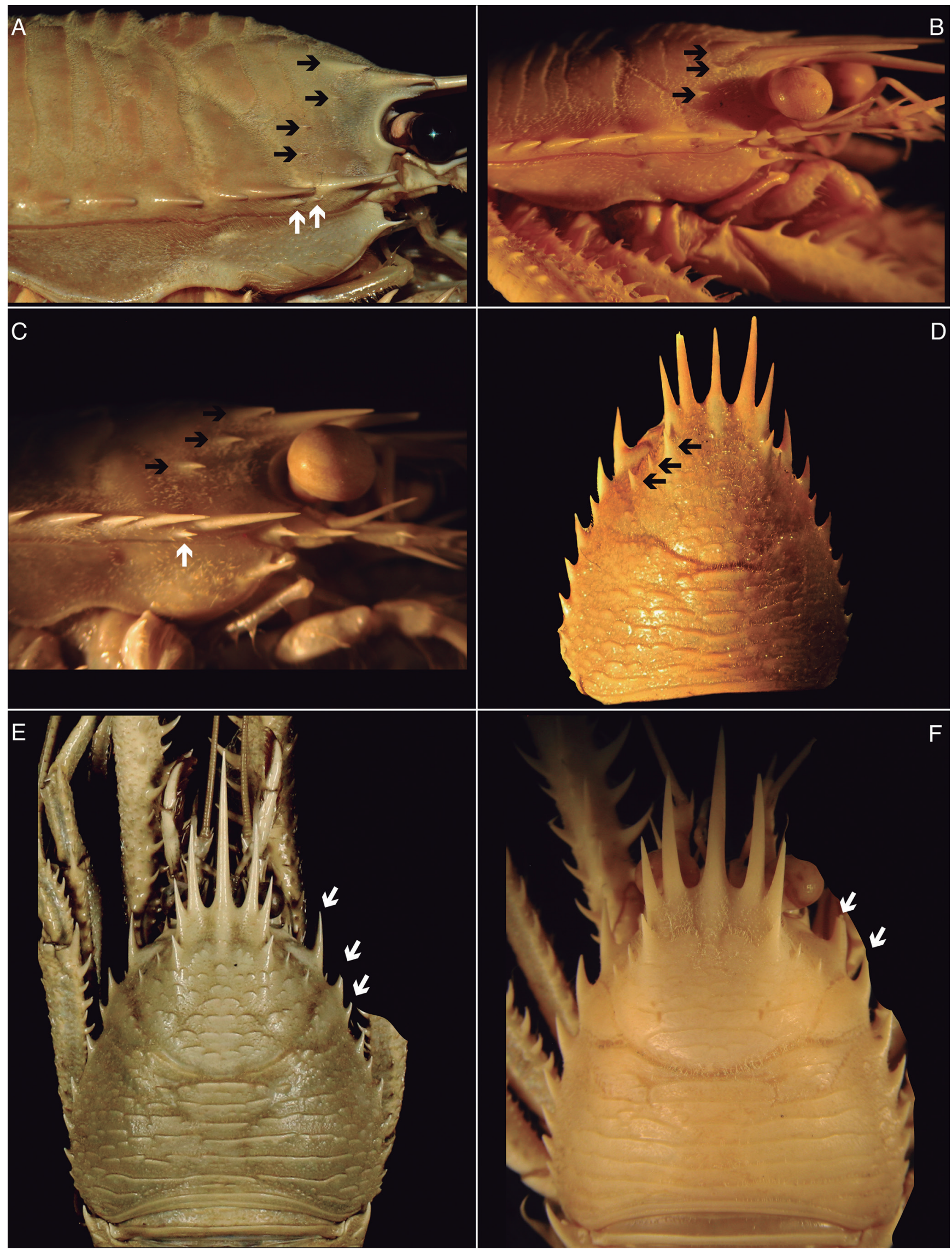

Figure 5. (A) Eumunida notialis sp. nov., holotype, male, cl 59 mm (MZUSP 25986). (B, F) Eumunida picta Smith, 1883, lectotype, male cl 16 mm (USNM 7304). (C, E) Eumunida bella de Saint Laurent \& Macpherson, 1990. (C) Paratype, male, cl 25 mm (USNM 22913). (E) Holotype, male cl 46 mm (MNHN Ga 517). (D) Eumunida squamifera de Saint Laurent \& Macpherson, 1990, paratype, female, Cl 24 mm (ICM 1042). (A-C) Anterior region of cephalothorax, lateral view; black arrows: hepatic spines; white arrows: inframarginal spines. (D) Carapace, dorsal view, pleonal segments cropped from image; arrows: hepatic spines. (E, F) Cephalothorax, dorsal view; arrows: carapace anterolateral spines. Photographs (5D, E) by E. Macpherson (ICM) and Laura Flamme (MNHN), respectively. 
(Figs. 1, 2, 5A, 6A). Two inframarginal spines below anterolateral spines (Figs. 1, 5A, 6A). Pterygostomial spine, strong, acute (Figs. 1, 5A, 6A); pterygostomial flap with few oblique striae. Branchiostegal area with sparse minute squamae, bordered with dense short setae anteriorly.

Sternal plastron medially concave; anterior margin of third thoracic sternite U-shaped, shallowly incised, with pair of obsolete, setiferous median processes (Figs. 1, 3A); fourth thoracic sternite with prominent lateral spine and setiferous transverse ridges (Figs. 1, 3A).

Second pleonal tergite as illustrated (Fig. 3C, G); two transverse ridges dorsally, few short striae laterally; anterolateral spine obsolete (Fig. 3G).

Rostral spine sharply spiniform (broken distally), slightly curved upwards, much longer than lateral supraorbital spines (Figs. 1, 2).

Eye extending far beyond end of lateral supraorbital spine; cornea strongly dilated, dark black (Fig. 5A).

First segment of antennal peduncle with short, acute, broad triangular, distolateral spine; second segment with well developed, sharp distolateral spine much shorter than mid-length of acicle; third segment with long distal spine, overreaching end of fourth segment (exclusive of subdistal, ventral spine); fourth segment with strong ventromesial spine slightly exceeding fifth antennal segment (exclusive of distal spines); fifth segment with three spines distally (mesial, lateral, ventromesial). Acicle spiniform, slender, extending almost to anterior margin of fourth segment (Fig. 7A).

Merus of third maxilliped with small, acute spine on distal third of mesial margin (Fig. 7E, F). Ischium crista dentata with 15-17 denticles (left and right ischium, respectively).

Chelipeds subequal, subcylindrical, $4.2 \mathrm{cl}$. Ischium squamate with strong, acute, ventromesial, subdistal spine, and several small, acute, ventral spines. Merus squamate, slightly less than twice carapace length, armed with four longitudinal rows of spines (mesial, dorsal, dorsolateral, ventromesial); mesial row alternating large and small strong spines; dorsal row with large and small, strong, acute spines; dorsolateral row with small, acute spines; ventromesial with small, acute spines. Carpus squamate, armed with three strong distal spines (dorsal, dorsomesial, ventromesial); two longitudinal rows of spines (dorsolateral and lateral rows with acute, blunt small spines, respectively; dorsomesial row absent). Palm and fixed finger squamate, densely covered with short, velvet-like setae; palm 1.4 times length of fixed finger, massive, without rows of spines (Fig. 4A-C). Chela with two pads, one large on ventral surface of palm near base of fixed finger, one small pad near base of dactylus (Fig. 4A). Dactylus squamate, densely covered with velvet, short setae. Fingers slightly gapping proximally, cutting margins as illustrated (Fig. 4A, B).

First three walking legs similar, squamate, sparsely furnished with long setae. Merus with strong, acute, distal spine on lateral surface. Extensor margins of merus and carpus with row of strong, acute spines, increasing in size anteriorly. Propodus slightly more than twice as long as dactylus, armed with row of 14-18 spinelets along flexor margin. Dactylus ending in corneous tip, with 10-12 movable, corneous spinules, along flexor margin. First walking leg with longitudinal row of strong, acute spines along flexor margin. Third walking leg with a longitudinal row of spinelets along lateral surface.

Remarks: Eumunida notialis sp. nov. (Fig. 2) is superficially similar to its Atlantic congeners in the possession of a pair of strong spines on the anterolateral margin of the fourth thoracic sternite (Figs. 1C, 3A, B), a distinct pad on the cheliped palm (Fig. 4A), eyes extending far beyond the end of the lateral supraorbital spines (Fig. 5A), and in having the lateral surface of the fourth pereopod merus with a longitudinal row of spines.

However, the new species differs from all its Atlantic counterparts in having (1) four hepatic spines, Figs. $1 A, B, 5 A, 6 A$ (versus three spines in the remaining Atlantic species, Figs. 5B-D, 6B-D; (2) two carapace inframarginal spines, Figs. 1A, 5A, 6A (versus one in E. bella and $E$. squamifera and no inframarginal spine in E. picta, Figs. 5B, C, 6B-D); (3) the distal end of the antennal acicle nearly reaching to the articulation between fourth and fifth antennal segments, Fig. 7A (versus antennal acicle distinctly overreaching the articulation between the fourth and fifth antennal segments, Fig. 7B-D); and (4) the anterolateral spine of the second pleonal tergite obsolete, Fig. 3C, G (versus anterolateral spine of the second pleonal tergite strong in the remaining Atlantic species, Fig. 3D-F, H).

The closest morphological resemblance of E. notialis sp. nov. is with E. picta of which it can be further separated by having one strong, acute spine on the anteroventrolateral angle of the fourth antennal segment, Fig. 7A (versus anteroventrolateral spine of the fourth antennal segment obsolete in E. picta, Fig. 7B).

The new species further differs from both E. bella and E. squamifera in the absence of a dorsolateral and dorsomesial, longitudinal rows of spines on the cheliped propodus, Fig. 4A-C (versus dorsolateral and dorsomesial, longitudinal rows of spines on the cheliped propodus present in both E. bella and E. squamifera (Fig. 4D, E, respectively).

Eumunida notialis sp. nov. additionally differs from $E$. bella in having (1) minute second and third hepatic spines, Figs. 1A, 5A (versus strong second and third hepatic spines in E. bella, Fig. $5 \mathrm{C}$ ) and (2) the anterior margin of the third thoracic sternum U-shaped, shallowly incised, Figs. $1 \mathrm{C}, 3 \mathrm{~A}$ (versus anterior margin of the third thoracic sternum deeply incised in E. bella, Fig. 3B), and further differs from $E$. squamifera in having the carapace ultimate transverse ridge entire across carapace, Figs. 1B, 3 C (versus carapace ultimate transverse ridge fragmented into short striae of variable length in E. squamifera, Fig. 3F).

According to de Saint Laurent \& Macpherson (1990) E. bella, E. picta and E. squamifera have three anterolateral spines on the carapace, although the presence or absence of the posteriormost spine varies over ontogeny in E. picta (posteriormost spine small in adults, lacking in young specimens). Conversely, Puillandre et al. (2011) attributed one anterolateral spine to both $E$. bella and E. squamifera, and two anterolateral spines to E. picta. The holotype of $E$. bella (adult, $\mathrm{cl} 46 \mathrm{~mm}$ ) and the lectotype of 

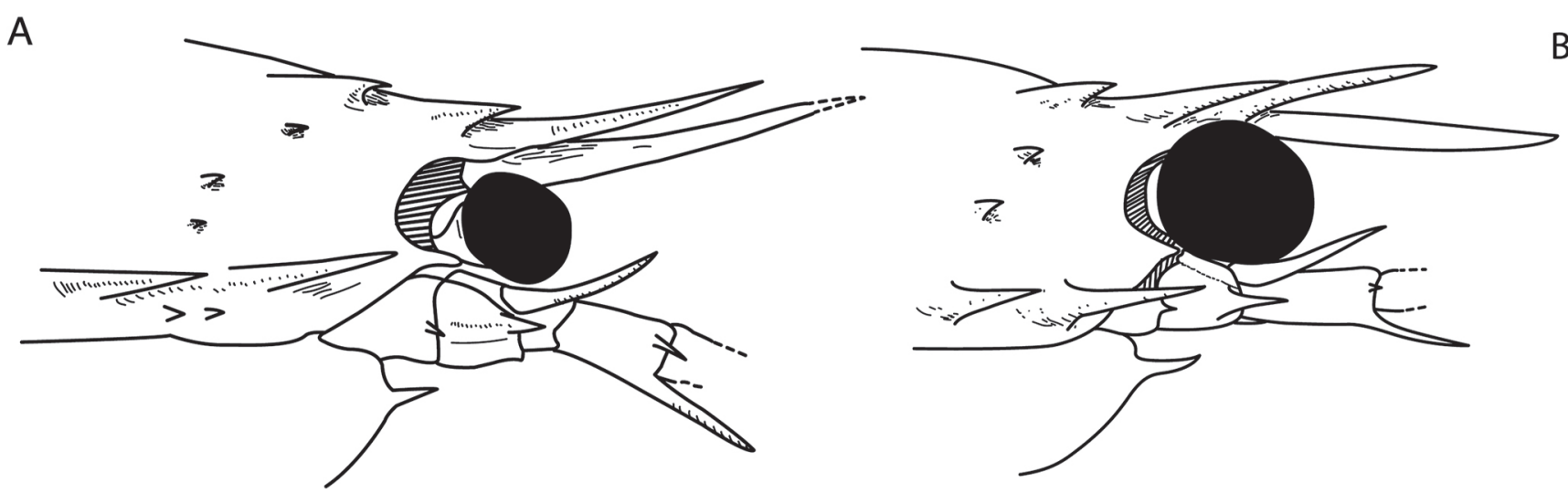

C
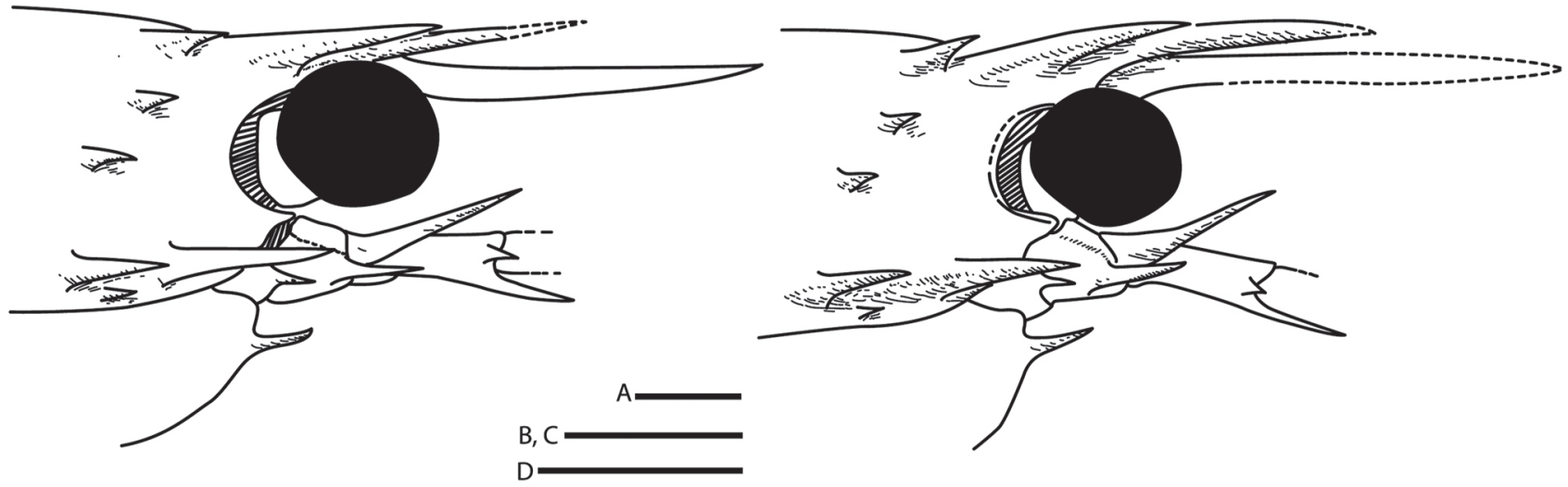

Figure 6. (A) Eumunida notialis sp. nov., holotype, male, cl 59 mm (MZUSP 25986). (B) Eumunida picta Smith, 1883, ovigerous female, cl 23 mm (USNM 98662). (C) Eumunida bella de Saint Laurent \& Macpherson, 1990, paratype, male, cl 25 mm (USNM 22913). (D) Eumunida squamifera de Saint Laurent \& Macpherson, 1990, paratype, female, Cl 24 mm (ICM 1042). (B-D) After de Saint Laurent \& Macpherson (1990: 654, fig. 4A-C). Note in (A) four hepatic spines and two inframarginal spines. Scale bars: $A-D=5 \mathrm{~mm}$.

E. picta (young, $\mathrm{cl} 16 \mathrm{~mm}$ ) have three and two anterolateral spines, respectively (Fig. 5E, F). The holotype of E. notialis sp. nov. (adult, cl $59 \mathrm{~mm}$ ) has three anterolateral spines, with the posteriormost one being minute (Fig. 2).

Baba \& Wicksten (2019) recently described E. subsolanus Baba \& Wicksten, 2019, which represented the first record of the genus from the eastern Pacific (Galapagos Islands). Eumunida subsolanus superficially resembles E. treguieri de Saint Laurent \& Poupin, 1996 from French Polynesia, and E. depressa de Saint Laurent \& Poupin, 1996, from Japan (viz. Baba \& Wicksten, 2019). Eumunida notialis sp. nov. can be distinguished outright from E. subsolanus in having four hepatic spines, four branchial marginal spines, and two inframarginal spines below the anterolateral spines (versus three hepatic spines, six branchial marginal spines, and no inframarginal spines below the anterolateral spines in E. subsolanus; viz. Baba \& Wicksten, 2019). Additionally, E. notialis sp. nov. (cl $59 \mathrm{~mm}$ ) is much larger than E. subsolanus (cl $6 \mathrm{~mm}$ ). The new species can be immediately separated from $E$. treguieri and $E$. depressa in having four longitudinal rows of spines on the merus of the chelipeds and the branchial region of the carapace evenly convex, respectively (versus three longitudinal rows of spines in $E$. treguieri and a depressed area on each lateral branchial surface of the carapace in E. depressa).

\section{Key to the Atlantic species of Eumunida}

1. Carapace (Fig. 1A, B) with 3 hepatic spines; 1 or no inframarginal spine (Fig. 6B-D). Antennal acicle (Fig. 1D) with distal end distinctly overreaching articulation between fourth and fifth antennal segments (Fig. 7B-D). Pleon with anterolateral spine of second tergite strong (Fig. 3H)

- Carapace with 4 hepatic spines and 2 inframarginal spines (Fig. 6A). Antennal acicle distal end nearly reaching to the articulation between fourth and fifth antennal segments (Fig. 7A). Pleon with anterolateral spine of second tergite obsolete (Fig. 3G).....

...Eumunida notialis sp. nov.

2. Carapace with 1 inframarginal spine; ultimate transverse ridge interrupted across carapace (Fig. 3E, F). Cheliped propodus with longitudinal rows of dorsolateral and dorsomesial spines (Fig. 4D, E) .

- Carapace without inframarginal spine; ultimate transverse ridge always entire across carapace. Cheliped propodus without longitudinal rows of dorsolateral and dorsomesial, spines

Eumunida picta

3. Carapace with ultimate transverse ridge interrupted laterally, entire medially (Fig. 3E). Third thoracic sternite deeply incised anteriorly (Fig. 3B). Eumunida bella

- Carapace with ultimate transverse ridge fragmented into short striae of variable length (Figs. 3F, 5D). Third thoracic sternite moderately incised anteriorly (Fig. 7G) .. Eumunida squamifera 

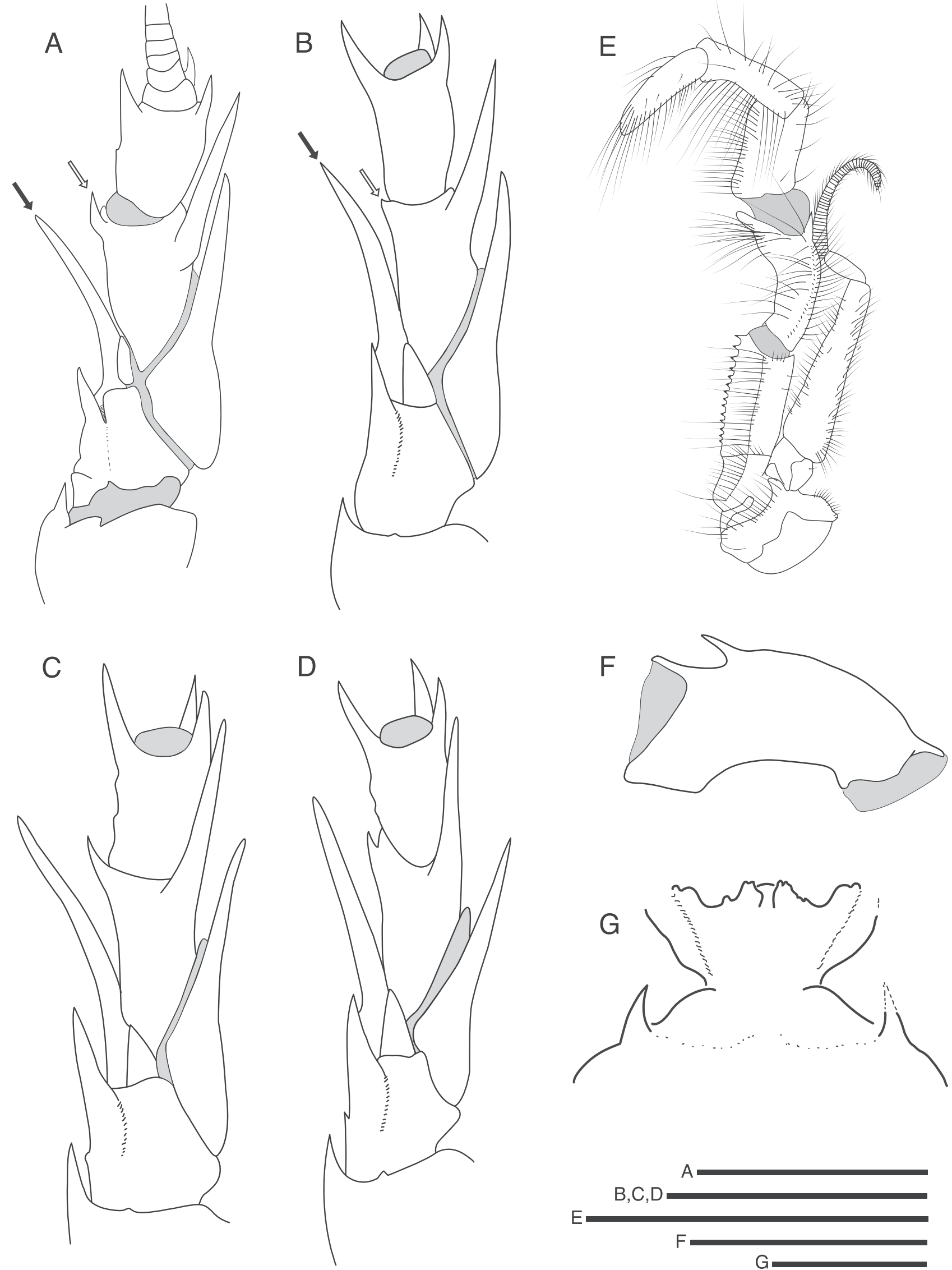

Figure 7. (A, E, F) Eumunida notialis sp. nov., holotype, male, cl 59 mm (MZUSP 25986). (B) Eumunida picta Smith, 1883, ovigerous female, cl 23 mm (USNM 98662). (C) Eumunida bella de Saint Laurent \& Macpherson, 1990, paratype, male, cl 25 mm (USNM 22913). (D, G) Eumunida squamifera de Saint Laurent \& Macpherson, 1990, paratype, female, cl 24 mm (ICM 1042). (A-D) Right antennal peduncle, ventral view. (E) Left third maxilliped, ventral view (Mxp3). (F) Mxp3 merus, mesial view. (G) Third and fourth thoracic sternites, ventral view. (B-D, G) After de Saint Laurent \& Macpherson (1990: figs. 6C, 8A-D). Scale bars: A, F= $10 \mathrm{~mm}, \mathrm{~B}-\mathrm{D}=5 \mathrm{~mm}$, $\mathrm{E}=20 \mathrm{~mm}, \mathrm{G}=3 \mathrm{~mm}$. Black arrow, antennal acicle. Empty arrow, antennal anteroventrolateral spine. 


\section{ACKNOWLEDGEMENTS}

We would like to express our gratitude to Paulo Pezzuto (Universidade do Vale do Itajaí, SC) for the donation of the material of Eumunida notialis sp. nov. to MZUSP, and to Rafael Lemaitre (USNM) for granting access to the collections under his responsibility and for providing working space to MT. We are grateful to Laure Corbari (MNHN) and Enrique Macpherson (ICM) for allowing the use of the photographs of the holotype of E. bella and paratype of E. squamifera from the MNHN, and the paratype of E. squamifera from the ICM, respectively. We also thank Joana d'Arc de J. Pinto, Maria José de S. Coelho (MZUSP) and Karen Reed (USNM) for their kind assistance throughout the execution of this work. We thank Shane Ahyong (Australian Museum, Sydney) and one anonymous referee for reviews and comments on the manuscript. MT thanks CNPq (Conselho Nacional de Desenvolvimento Científico e Tecnológico - Brasil) (Produtividade, 303122/2016-1) for funding studies on the taxonomy of decapod crustaceans. DL thanks CAPES-Brazil for a post-doctoral grant (process number EXPPD000426). This study was financed in part by CAPES (Coordenação de Aperfeiçoamento de Pessoal de Nível Superior - Brasil) - Finance Code 001.

\section{REFERENCES}

Baba, K. \& Wicksten, M.K. 2019. Chirostyloidean squat lobsters (Crustacea: Decapoda: Anomura) from the Galapagos Islands. Zootaxa, 4564(2): 391-421.

Baba, K.; Ahyong, S.T. \& Macpherson, E. 2011. Morphology of marine squat Iobsters. In: Poore, G.C.B.; Ahyong, S.T. \& Taylor, J. (Eds.). The biology of squat lobsters. Melbourne, CSIRO Publishing. p. 1-37.

Baba, K.; Macpherson, E.; Poore, G.B.; Ahyong, S.T.; Bermudez, A.; Cabezas, P.; Lin, C-W.; Nizinski, M.; Rodrigues, C. \& Schnabel, K.E. 2008. Catalogue of squat lobsters of the world (Crustacea: Decapoda: Anomura-families (hirostylidae, Galatheidae and Kiwaidae). Zootaxa, 1905: 1-220.

Chace Jr., F.A. 1942. Reports on the scientific results of the Atlantis expeditions to the West Indies, under the joint auspices of the University of Havana and Harvard University. The Anomuran Crustacea. I. Galatheidea. Torreia, 11: 1-106.

d'Udekem d'Acoz, C. 1999. Inventaire et distribution des crustacés décapodes de l'Atlantique nord-oriental, de la Méditerranée et des eaux continentales adjacentes au nord de $25^{\circ} \mathrm{N}$. Collection Patrimoines naturels/Museum National d' Histore Naturelle, Paris, 40: i-x, 1-383.

de Saint Laurent, M. \& Macpherson, E. 1990. Les espèces atlantiques du genre Eumunida Smith, 1883 (Crustacea: Decapoda: Chirostylidae). Journal of Natural History, 24: 647-666.

de Saint Laurent, M. \& Poupin, J. 1996. Crustacea, Anomura: Les espèces indo-ouest pacifiques du genre Eumunida Smith, 1880 (Chirostylidae). Description de six espèces nouvelles. In: Crosnier, A. (Ed.). Résultats des Campagnes MUSORSTOM. Vol. 15. Mémoires du Museum National d'Histoire Naturelle, Paris, 168: 337-385.

Matos-Pita, S.S. \& Ramil, F. 2014. Squat lobsters (Anomura) from Mauritanian Waters (West Africa), with the description of a new species of Munidopsis. Zootaxa, 3765(5): 418-434.

Milne-Edwards, A. \& Bouvier, E-L. 1900. Crustacés Décapodes. I. Brachyoures et Anomoures. Expéditions scientifiques du Travailleur et du Talisman pendant les années 1880, 1881, 1882, 1883. Paris, Masson. 396p., 32 pl.

Puillandre, N.; Macpherson, E.; Lambourdière, J.; Cruaud, C.; BoisselierDubayle, M-C. \& Samadi, S. 2011. Barcoding type specimens helps to identify synonyms and unnamed new species in Eumunida Smith, 1883 (Decapoda: Eumunididae). Invertebrate Systemtics, 25(4): 322-333.

Smith, S.I. 1883. Preliminary report on the Brachyura and Anomura dredge in deep water off the South Coast of New England by the United States Fish Commission in 1880, 1881, and 1882. Proceedings of the United States National Museum, 6(1-4): 1-57, $6 \mathrm{pl}$.

Wenner, E.L. 1982. Notes on the distribution and biology of Galatheidae and Chirostylidae (Decapoda: Anomura) from the Middle Atlantic Bight. Journal of Crustacean Biology, 2(3): 360-377. 